\title{
Zdzisław Gawlik
}

Maria Curie-Skłodowska University in Lublin, Poland

ORCID: 0000-0002-4809-0231

zdzislaw.gawlik@umcs.pl

\section{Selected Institutions of the Polish Private Law for the Protection of the Creditor}

\author{
Wybrane instytucje polskiego prawa prywatnego dla ochrony \\ wierzyciela
}

ABSTRACT

The subject of this article is the issue of the intensity of the protection of interests of a person who has entered into the orbit of obligatory relations. Institutions used to secure a claim are described, but doubts arise when the securities overlap and multiply when the debtor is declared bankrupt. Not every business venture is successful. Often, for reasons beyond the entrepreneur's control, he is unable to pay debts owed to his creditors. The creditors, on the other hand, aware of the risk of entering into a contract, seek security to be established. Therefore, it is worth considering how the security should be treated in the event of the debtor's insolvency. The study indicates that the creditor's "own securities", both personal and material, take precedence over the creditors who receive priority as a result of the debtor's ineffectiveness under the provisions on the actio Pauliana. The author defends the position according to which the precedence referred to in Article 532 of the Civil Code is not the absolute precedence. The problems discussed in the study are of great interest for many representatives of the doctrine and courts. Moreover, with regard to their content, the Polish Ombudsman formulated questions about their compliance with the Constitution of the Republic of Poland. Poland's adoption of the market economy model makes these problems typical not only for Poland. A number of arguments were put forward to defend the view on the precedence of the security taken by the creditors over the priority granted by the actio Pauliana. To eliminate doubts as to the reciprocal relationship of priorities to pay the claims, an appropriate proposal for the law as it should stand (de lege ferenda) has been put forward.

Keywords: the Polish private law; protection of the creditor; debtor's insolvency; actio Pauliana; secure a claim; absolute precedence; bankruptcy

CORRESPONDENCE ADDRESS: Zdzisław Gawlik, PhD, Dr. habil., Associate Professor, Maria Curie-Skłodowska University (Lublin), Faculty of Law and Administration, Institute of Law, Plac Marii Curie-Skłodowskiej 5, 20-031 Lublin, Poland. 


\section{INTRODUCTION}

The problem of evading the fulfilment of one's obligations takes place not only in the modern world, but it has appeared since the beginning of the existence of legal obligations, when debtors resorted to various ways to avoid debt repayment. As early as in Roman law, the institution of actio Pauliana appeared, which has survived to this day with some modifications resulting from changing legislation and is often used to protect the creditor's interest against the actions of the debtor, who due to his dispositions depletes his assets to the extent threatening or even preventing him to meet the creditor's interests. ${ }^{1}$ The social and economic changes which took place in Poland at the turn of the 1990s resulted, on the one hand, in the emergence of many entities participating in the market game, and, on the other hand, many entities falling into a situation of financial crisis, measured by the loss of payment capacity, i.e. inability to pay their liabilities as these falls due. It also happens, however, that failure to meet obligations results from deliberate or conscious action by the debtor. The construct of creditor protection provided for in Articles 527 to 34 of the Polish Civil Code, by challenging the transaction intentionally detrimental to the creditor, performed by the debtor with a third party, leading to or aggravating the debtor's insolvency, is not the only tool provided by law for this purpose. ${ }^{2}$ This construct is further modified, i.a., by the provisions of the Bankruptcy Law (Articles 127 to 135).

\section{RESEARCH PART}

\section{Ineffectiveness of a contract the performance of which makes it wholly or partly impossible to satisfy a third party's claim}

One of the other legal tools protecting the creditor against a debtor who not only fails to perform his performance voluntarily, but also hinders the creditor's enforcement of his rights, is Article 59 of the Civil Code. It allows to satisfy the

1 The institution of actio Pauliana comes from Roman law. It is believed by historians of law that it was introduced by praetor Lucius A. Paulus (around 191 B.C.). The aim of actio Pauliana is to obtain by the creditor the due payment in a situation where the debtor is liquidating his property that may be used to satisfy the creditors' claims.

2 An example of growing doubts, and at the same time interest in the problem, is another question that was filed with the Supreme Court on 30 March 2021 (III CZP 23/21), whether the creditor, for whom the contract of transfer of the right of perpetual usufruct entered into between the debtor and a third party was deemed ineffective, may claim payment from this right, which, as a result of the transaction deemed ineffective, left the debtor's property, with priority over third party creditors whose claims have been secured by a mortgage established on this right. 
creditor's claim by declaring the debtor's later contract ineffective towards the creditor, if the execution of this contract would render satisfaction of the earlier claim impossible. ${ }^{3}$ The purpose of this construct is therefore not "to satisfy the creditor in general in every possible way, including by way of compensation for damage, but effective satisfaction of the claim", ${ }^{4}$ corresponding to the content of the obligation. The right holder does not have in this situation a direct claim for the release of the property against the property holder, but only the right to demand that the subsequent contract be declared ineffective, and consequently that enforcement be carried out from the assets of the person who concluded as a second entity the contract with the debtor. Due to the similarity of actio Pauliana and Article 59 of the Civil Code, intended to protect the creditor, the problem of their mutual relationship emerges. The objective fact of breaching the creditor's rights is not sufficient for both claims to arise, since certain prerequisites of a subjective nature are also required, namely a reprehensible state of mind of the third party and the debtor. ${ }^{5}$

The fundamental difference between these institutions boils down to the fact that Article 59 of the Civil Code does not protect the creditor from the effects of the debtor's bad financial situation. The protection provided by this provision may be applied even when the debtor is solvent and can fulfill any other performance besides the one he was obliged to perform towards the claimant creditor. ${ }^{6}$ For these reasons, the interest in this study is focused only on the problem of actio Pauliana in conjunction with tangible securities established for the protection of the creditor. It should also be noted that there are many more problems associated with the existence and implementation of the purposes for which actio Pauliana was intended. This is probably due to the fact that the institution of actio Pauliana is well suited to simple tripartite systems in which a third party obtains a material benefit, and begins to seriously fail in cases where the debtor has more than one creditor. ${ }^{7}$ Matters are often further complicated when the debtor is declared bankrupt, given that certain other events occur over time. In such circumstances, two tools designed to protect creditors' interests overlap - those under the Civil Code and those which define the effects of declaring the creditor's debtor bankrupt.

${ }^{3}$ S. Rudnicki, [in:] Komentarz do kodeksu cywilnego. Księga pierwsza. Część ogólna, eds. S. Dmowski, S. Rudnicki, Warszawa 2004, p. 245; A. Janiak, [in:] Kodeks cywilny. Komentarz, vol. 1: Część ogólna, ed. A. Kidyba, Warszawa 2012, p. 360.

4 A. Ohanowicz, Przepis art. 59 k.c. a tzw. ius ad rem, "Państwo i Prawo" 1966, no. 11, p. 689.

5 A. Kubas, Rozszerzona skuteczność wierzytelności, "Studia Cywilistyczne" 1969, vol. 13-14, p. 218.

${ }^{6}$ M. Pyziak-Szfnicka, Ochrona wierzyciela w razie niewypłacalności dtużnika, Warszawa 1995, p. 50.

${ }^{7}$ P. Klaczak, K. Mularski, Skarga pauliańska a zaspokojenie przez dtużnika jednego z jego wierzycieli, "Transformacje Prawa Prywatnego" 2020, no. 4, p. 99. 


\section{Debtor's bankruptcy and a prior disposition of a real property}

It is probably not quite rare that after one of the entities has disposed of the property, a creditor of this entity applies against the purchaser of the property to declare the transaction of disposal of the property ineffective with regard to him. Such a demand may be upheld and the defendant may take action to defend his right. It is possible that the entity disposing the property will be declared bankrupt after a judgement declaring the sale of the property ineffective, and a trustee may take the place of the property disposer.

In such circumstances, it would be difficult for the defendant to challenge the decision of the court of first instance on the effectiveness of the disposal of the property to the disadvantage of one of the creditors. However, the following questions arise in this situation:

1. Is the legal transaction on disposal of the property ineffective in relation to the bankruptcy estate without limitations?

2. Is the legal transaction ineffective in relation to the bankruptcy estate, but on a similar basis as requested before the court of first instance by one of the creditors, who applied for the sale of property to be declared ineffective?

This situation makes it evident that the appeal against the decision declaring the property disposal transaction to be ineffective may be brought by the property purchaser. The defendant will therefore endeavour to challenge the judgement disqualifying the disposal of the property at the request of the creditor who did so in respect of claims against the entity who disposed of the property and was subsequently declared bankrupt.

The creditor's action before the court of first instance was aimed at protecting and satisfying creditor's interests, measured by the size of the claim. His interests in this area do not and could not reach beyond the claim. The defendant, on the other hand, had the right, and at the same time the duty, to take action to protect his interests by appealing against the decision on the effectiveness of the disposition of the property. It is difficult to imagine a situation in which an interested party appeals against an unfavourable decision of the court of first instance while expecting an even less favourable decision from the point of view of one's legal and economic interests. As a rule, the appeal is lodged by a party dissatisfied with the decision of the court of first instance in order to defend that party's interests.

In one of its rulings, the Supreme Court stated unequivocally that a party may not appeal against a judgement that is favourable to that party. ${ }^{8}$ If the goal of the appeal is to renew and supplement the proceedings before the first-instance court, in order to verify the reasonableness and legality of the appealed decision within

${ }^{8}$ Decision of the Supreme Court of 13 August 1997, I CKN 207/97; decision of the Supreme Court of 5 September 1997, III CKN 152/97. 
the limits of the appeal, i.e. to examine the case within the same limits within which the first-instance court was authorised to examine it, then the outcome of such a decision should not have less favourable consequences for the appellant than the outcome of the first-instance decision. The consideration of the appeal should lead to correction of possible errors made by the court of first instance. In the circumstances described above, the purchaser questions the ineffectiveness of the disposition in relation to the creditor. The legal interest of the appeal is expressed in the need to amend or annul the appealed decision, from the perspective of the applicant's benefit. The appeal is justified by the fact that the appellant does not obtain such legal protection as he was entitled to expect. An appeal is a legal remedy aimed at amending or, exceptionally, repealing the first-instance judgement by way of a re-examination of the same case by another court, usually of a higher rank. The trial of a case by the higher-instance court is a continuation of the trial initiated before the first-instance court. ${ }^{9}$

The higher-instance court assesses the relevance (rightness) of the appealed decision. Presenting new statements and taking new evidence is, in principle, inadmissible. ${ }^{10}$ If we assume in the present case, even from a theoretical point of view, that the appellant's conduct was not in his own interest, but in the interest of possible other creditors who might benefit from a decision making the legal transaction ineffective for the bankruptcy estate without limitations, such conduct would not be worthy of protection. It may happen that the plaintiff is an entity that includes many stakeholders (e.g., a limited liability company, irrespective of the number of shareholders and their shares). If, in such circumstances, we accept the intention of the officeholder (the management board or any other person authorised to represent the entity) to act before a court in the interests of creditors other than the applicant at the first instance, such conduct would have to be treated as acting against the interests of the company and shareholders. Such type of conduct is not justified by law and is even criminalised. Thus, a thesis must be defended here in this situation that "the debtor's creditors who have failed to challenge the legal transaction carried out by the debtor with detriment to them and have no writ of execution against a third party may not participate at all in the enforcement carried out as a result of admission of actio Pauliana". ${ }^{11}$

This view is also justified by the fact that the debtor's right is, unless otherwise provided for by law, to satisfy the creditor of his choice, in a situation where there are many creditors, if the debtor's assets are not sufficient to cover all liabilities.

9 J. Gudowski, Pogląd na apelację, [in:] Aurea praxis. Aurea theoria. Ksiegga pamiatkowa ku czci Profesora Tadeusza Erecińskiego, eds. J. Gudowski, K. Weitz, vol. 1, Warszawa 2011, p. 250.

10 A. Pastuszka, Prawo procesu cywilnego, Lublin 1937, p. 271.

${ }^{11}$ M. Sychowicz, [in:] Komentarz do kodeksu cywilnego. Ksiega trzecia. Zobowiązania, ed. G. Bieniek, vol. 1, Warszawa 2007, p. 711. 
It should be assumed that creditors, by failing to challenge the debtor's actions, respected the debtor's right to choose a creditor. In such circumstances, it would be difficult to formulate moral accusations against the debtor. ${ }^{12}$ This is because the legislature does not specify the order in which the debtor should satisfy his creditors, except specific provisions (e.g., Article 124 of the Civil Procedure Code). This entitles the debtor to choose a creditor whose claim will be repaid by him. In view of the above, there is a reasonable risk that any creditor who has been omitted by the debtor will be dissatisfied if another creditor is selected and repaid. The debtor's insolvency makes it impossible to satisfy all creditors. It must be recognized that such a risk is assumed by every creditor who has not tried to secure his claims. ${ }^{13}$ Creditors who have not established special securities, in kind or in person, must be exposed to the adverse effects of changes in the debtor's assets, including those caused by the debtor's actions. ${ }^{14}$ The mere existence of a claim does not and cannot deprive the debtor of the right to dispose of his property (an example of which is a mortgage-backed property). Therefore, it must be assumed that the rights of creditors are essentially equal, if they do not enjoy the privileges guaranteed by law, nor have they themselves made efforts to establish additional security in case of future events violating the security of claims.

Therefore, only this legal transaction of the debtor may be declared ineffective, even up to the maximum size of the debt owed to the creditor who challenged the transaction. It is only him who has the possibility of carrying out enforcement against the property of a third party. ${ }^{15}$ Therefore, assuming that the legal transaction of selling real property is ineffective in relation to the bankruptcy estate without limitations, it would constitute a kind of bonus for other parties than the creditor who challenged the transaction. The reason for this is that something happened that is beyond their control (the debtor's declaration of bankruptcy), which meant that the trustee in bankruptcy appeared in the place of the original debtor. Such behaviour is unacceptable, not only from a legal point of view, because it affects the certainty of legal transactions, but it is also difficult to accept it from an ethical and moral point of view. This is especially true when there is a private plaintiff in the trial and the trustee appears in the appeal proceedings. It also seems that it is not without significance that since other parties than the creditor who challenged the transaction did not discredit his actions, they respected his choice of the creditor whose debt was settled. Declaring the ineffectiveness of the transaction in relation to all debtor's claims, is a bonus for all creditors, even if they did not expect any such benefits.

12 R. Longchamps de Bérier, Zobowiazania, Poznań 1999, p. 431.

13 M. Pyziak-Szafnicka, Glosa do wyroku SN z 24.10.2002, II CK 396/02, “Orzecznictwo Sądów Polskich" 2003, no. 11, item 141.

${ }_{14}$ R. Longchamps de Bérier, op. cit., p. 431.

15 Judgement of the Supreme Court of 28 November 1995, I CRN 218/95. 
Although Article 383 of the Code of Civil Procedure states that in appeal proceedings the claim may not be extended or new claims may not be put forward, while at the same time assuming the possibility of demanding, in the event of a change in circumstances, the equivalent value or another object instead of the original object of the dispute. ${ }^{16}$ That fact does not automatically mean that a change in the circumstances on which the law makes dependent the possibility of extending the statement of claim is an unrestricted prerequisite for submitting new claims as part of the appeal.

When the debtor is declared bankrupt, the object of the dispute has not changed and still covers the ineffectiveness of the legal transaction against the purchaser of the property. There is no other object of dispute in this situation.

The appeal proceeding is, on the one hand, of a substantive nature and, on the other, constitutes a review of a specific decision. The appeal procedure is also characterised by the fact that it must correspond to the object of the dispute referred to at first instance by the initiator of the proceedings (the plaintiff). Therefore, it should be assumed with regard to the question referred above that the answer is the wording of Article 383 sentence 1 of the Code of Civil Procedure, but Article 383 sentence 2 of of the Code of Civil Procedure is not applicable here, because we are not dealing with a change in the value or the subject of the dispute.

The possibility to submit new facts or evidence may relate only to the same substantive-law claim or legal relationship from which the plaintiff derives its procedural claim, as well as from procedural prerequisites. ${ }^{17}$

In the legal and factual state described herein, however, we are dealing with an event such as the declaration of bankruptcy of an entity disposing of real estate to the detriment of one of its creditors, which results in the necessity to look at the situation of both the bankrupt and its creditors. In these circumstances, a trustee in bankruptcy enters into the rights of the bankrupt, with the right to enter the appeal case in place of the original plaintiff.

At the same time, it should be noted that it is not always the case that one or several creditors make efforts to protect their rights prior to the declaration of bankruptcy of an entity, e.g. by bringing actio Pauliana. ${ }^{18}$

${ }^{16}$ M.P. Wójcik mentions factual circumstances which justify the extension of the statement of claim or submission of new claims. See M.P. Wójcik, [in:] Kodeks postępowania cywilnego. Komentarz, ed. A. Jakubecki, Warszawa 2012, p. 515.

17 J. Bodio, Wymagania formalne apelacji i skutki ich nieuwzględnienia, [in:] Jus et remedium. Ksiega jubileuszowa Profesora Mieczysława Sawczuka, eds. A. Jakubecki, J.A. Strzępka, Warszawa 2010, p. 73.

${ }_{18}$ On the complexity of the problem, see A. Jakubecki, Ogłoszenie upadtości strony procesu cywilnego - uwagi na tle nowelizacji Kodeksu postepowania cywilnego, "Przegląd Sądowy" 2007, no. 7-8, p. 27. 
Being aware of such a situation and associated risks for the creditors, the provisions of the Bankruptcy Law provide in Article 127, in case the debtor is declared bankrupt, a solution pursuant to which legal transactions performed by the bankrupt within a year prior to the date of filing the petition for bankruptcy are ineffective in relation to the bankruptcy estate. The effect described in this provision depends on the disposition of assets by the debtor if the disposition has been made free of charge or for a consideration, but the value of the benefit of the bankrupt exceeds, to a considerable degree, the value of the performance received by the bankrupt or reserved for the bankrupt or a third party. This solution is intended as a tool preventing the bankrupt from entering into transactions which are intentionally detrimental to creditors.

It is worth noting that, in these circumstances, the ineffectiveness of transactions made by the bankrupt within a specified period depends on the demonstration of a gross detriment to the person making the transaction (the bankrupt). This means that not every transaction of the bankrupt that leads to depletion of his assets may be contested by the trustee under the provisions of the Bankruptcy Law, but only the one in which there is a gross disproportion between the performances of the bankrupt and of the other party to the transaction.

The burden of proof that the value of the bankrupt's performance significantly exceeds the value of the performance received by the bankrupt rests with the person who questions the transaction, i.e. the trustee in bankruptcy. The above-mentioned tool is intended for not only the trustee in bankruptcy, but every plaintiff, including a private one. The concept of "gross non-equivalence of performances" is vague and may raise doubts, so a legal transaction may be qualified to this category in the specific circumstances of a given case, using objective market measures of the performances covered by the protection. On the other hand, for actio Pauliana, apart from other conditions for demanding a legal transaction to be considered ineffective, there is also the condition of "the performance of a legal transaction with detriment to creditors, with a third party gaining a financial benefit". It should therefore be noted that the Civil Code provides a very wide range of possibilities to contest transactions, compared to the protection granted to the creditor in the Bankruptcy Law. These possibilities go much further towards protecting the interests of the creditor than it is in the case of the use of actio Pauliana only.

A question may be asked about the protection intended to protect the rights of the creditor within the meaning of the Bankruptcy Law, and provided for in the provisions of the Civil Code, through the construction of actio Pauliana. At this point, it should be noted that:

- the legislature, being aware of the occurrence of events related to the behaviour of debtors at every stage of their contractual activity, for reasons both dependent on them and independent, which lead to the depletion of 
their assets to a degree compromising the security of creditors, has provided a number of tools dedicated to the protection of the creditor's interest,

- the legislature is aware and notices that the debtor's actions aimed at reducing his assets often intensify too much in the face of the debtor's bankruptcy, and consequently introduces appropriate solutions,

- in any case, the trustee in bankruptcy (as well as private entities) has more legal possibilities to take effective action aimed at protecting the interests of the bankrupt's creditors as much as possible, using the solutions provided for by the Bankruptcy Law (Article $127 \mathrm{ff}$.), as well as general rules of law applicable in circumstances prescribed by civil law (Article $527 \mathrm{ff}$. of the Civil Code),

- the legislature, providing the trustee in bankruptcy with very far-reaching instruments to protect the interests of creditors, does not, however, grant the trustee the right to take any action to protect the interests of the creditor or the bankruptcy estate, if a relevant claim is sought by the trustee. The protection provided for in the provisions of the Civil Code covers the ineffectiveness in relation to the designated creditor, while in the light of the provisions of the Bankruptcy Law the transaction is ineffective in relation to the bankruptcy estate, which directly transfers to the bankrupt's creditors,

- as a consequence of the described legislation, there is no doubt that the court of appeal, confirming the rightfulness of the decision of the court of first instance on the ineffectiveness of the real property sale contract, cannot extend this ineffectiveness as requested by the trustee in bankruptcy replacing the original plaintiff, against the bankruptcy estate without limitations, but only as requested by the original plaintiff. According to the sequence of actions taken and events, only the creditor who took steps to protect his rights may be protected, and not other creditors of the debtor.

Summing up the considerations in this part, it seems reasonable that, in the light of the described facts and legislation, the object of the proceedings before the court of second instance delimited by the appeal may not exceed the statement of claim, and, consequently, the court of appeal may adjudicate on the ineffectiveness of the legal transaction in relation to the bankruptcy estate, but limited to the amount of the claim of the original plaintiff.

\section{Priority under Article 532 of the Civil Code and tangible securities of claims}

As regards the priority issue referred to in Article 532 of the Civil Code, it should be noted that the crucial consequence of the decision made as a result of actio Pauliana is that the creditor, having priority over the creditors of the third party, can be satisfied from the assets belonging to the third party which, as a re- 
sult of the contested action, have left the debtor's assets or have not entered the debtor's assets. ${ }^{19}$

The moment such a decision becomes final means the maturity of the debt, and where the asset is real property, this right may be disclosed in the land and mortgage register. ${ }^{20}$ The Supreme Court assumed that the creditor's right under Article 532 of the Civil Code does not generate a conflict of law between the legal status of the property disclosed in the land and mortgage register and the actual legal status, nor does it invalidate erga omnes the acquisition of property by a third party. This creditor's right cannot also invalidate any other right in rem disclosed in the land and mortgage register, including a mortgage.

Such an effect would have to result directly from a legal provision but there is no provision having such effect. Even if such an absurd assumption were to be made, this right could further invalidate any other rights in rem, e.g. a transmission easement or right-of-way, leading in extreme situations to the results even in the form of the inability to use a house supplied with certain utilities (water, gas, electricity) under the said transmission easement. Special provisions provide for the termination of the mortgage, i.a., in the case of the sale of the property during the enforcement and bankruptcy proceedings or the acquisition of the property under the expropriation rules. In all these cases, however, the mortgage creditor may demand payment of the secured claim from the price obtained from the sale of the property encumbered with the mortgage or compensation for the right lost. It would therefore be difficult to deprive of protection the mortgage creditor in the event that the legal transaction is declared ineffective through actio Pauliana.

It should also be borne in mind that the erga omnes effectiveness of mortgage is also expressed in the possibility of requesting discontinuation of any act directed at the encumbered property which could result in a reduction in its value to an extent that endangers the security of the mortgage (Article 91 of the Act on land registers and mortgage). The protection of mortgage is of an objective nature, i.e. independent of the infringer's fault.

The Supreme Court states in the above-mentioned decision that the right acquired as a result of actio Pauliana deserves the effectiveness referred to in Article 17 of the Act on land registers and mortgage. At the same time, according to the Court, such an entry to the register prevents the creditor from the possibility of actio Pauliana brought against another purchaser of the property.

One can hardly disagree with such a justification and, consequently, it must be accepted that the gradation of rights disclosed in the land register cannot be

19 P. Machnikowski, [in:] Kodeks cywilny. Komentarz, ed. E. Gniewek, Warszawa 2006, p. 911; W. Popiołek, [in:] Kodeks cywilny, vol. 2: Komentarz do artykułów 450-1088, ed. K. Pietrzykowski, Warszawa 2011, p. 222.

${ }^{20}$ Decision of the Supreme Court of 26 October 2005, V CK 776/04. 
considered reasonable due to the moment when the land register entry is made and in view of the circumstances for which it is made. The encumbrance of the sold property for the benefit of creditors of the purchaser is not detrimental to the mortgage creditor of the vendor. ${ }^{21}$

In general, it must be assumed that actio Pauliana protects creditors who have no tangible security. A creditor who managed to secure his right in such manner (or other established other security, including personal) ${ }^{22}$ does not have to fear the debtor's non-reliability or ineptness, because in any case he will be able to satisfy his claim from the security (the perception of mortgage in the Polish legal system coincides with the concept of mortgage in most European countries). ${ }^{23}$

As a rule, the sale of mortgaged property does not harm the creditor, as the possibility to satisfy the claim from the property is not affected. However, in a different position is any other creditor who has not made efforts to secure his claim. In his situation, any further encumbrance on the debtor's assets poses a risk to him. Therefore, as far as he is concerned, he should be able to challenge the establishment of a tangible security by the securing creditor. ${ }^{24}$ As regards his person, he should be protected not by justifying the priority under Article 532 of the Civil Code over tangible securities, but by exercising his right to seek declaration of the transaction establishing a tangible security as ineffective under Article 531 of the Civil Code. Assuming theoretically the priority under Article 532 of the Civil Code over creditors secured with a physical collateral, we would in a way reward creditors who make no effort to secure their claims. It would be pointless for a creditor to afford time and financial efforts to secure his claim. It would be a waste of money and time, because it would be possible to do nothing and then make use of Article $527 \mathrm{ff}$. of the Civil Code in the case of a risk to the repayment of one's claims.

In any case, creditors who did nothing to secure their rights should not be preferred to creditors who, convinced that a tangible security was effective, made efforts to provide such security. It is common knowledge that there are debtors who are unreliable, and sometimes those merely inept, incompetent or who just faced unfavourable circumstances. A prudent creditor, aware of the dangers the debtor may encounter in the performance of his obligation, establishes a security, preferably in kind, given the nature and effectiveness of the security.

${ }^{21}$ The order in which the mortgages are created is decisive in this situation. See M. Pyziak-Szafnicka, [in:] System Prawa Prywatnego, vol. 6: Prawo zobowiąań - część ogólna, ed. A. Olejniczak, Warszawa 2009, p. 1286.

${ }^{22}$ R. Longchamps de Bérier (op. cit., p. 431) notes that most exposed to adverse effects of changes in the debtor's assets are those creditors who had failed to establish particular securities, whether tangible or personal.

23 J. Pisuliński, [in:] System Prawa Prywatnego, vol. 4: Prawo rzeczowe, ed. E. Gniewek, Warszawa 2005, p. 527.

${ }^{24}$ M. Pyziak-Szafnicka, Ochrona wierzyciela ..., p. 218. 
If we were to assume that Article 532 of the Civil Code takes precedence over physical collateral, we would be favouring careless, unaware creditors, or those who tend to expect that "things will work out somehow". It would then be necessary to ask why the protection of a creditor who does not take action to secure a claim should reach much further than the protection of a creditor who does make such efforts. Besides, both systems of protection, the one based on actio Pauliana and the one based on the system of physical collateral, are in the interest of creditor protection. In this situation - assuming that the priority under Article 532 of the Civil Code is given preference over the priority described in Article 65 of the Act on land registers and mortgage - it is hard to treat the less prudent better than the prudent one.

In such circumstances, it should also be pointed out that a creditor using a mortgage as a security may make use, to protect his right, the claims provided for each creditor referred to in Article 527 of the Civil Code. However, the fulfilment of that claim depends on the fulfilment of a number of conditions which the creditor is required to prove.

However, in the exercise of the mortgage security and the privileges attached to the right in rem, the creditor does not incur the risk of failure to prove the circumstance under Article 527 of the Civil Code. ${ }^{25}$ The security by mortgage seems to give the creditor the guarantee that cannot be offered by actio Pauliana. The need to bear the costs of bringing an action against the purchaser would also be relevant in those circumstances.

For the mortgage creditor, it is irrelevant that any owner of the encumbered property is declared insolvent, just as changes in the ownership of the encumbered property are not of greater importance, since each subsequent owner becomes a mortgage debtor. The mortgage-backed creditor can still satisfy his claim from the encumbered property.

The moment the mortgage is established determines the effectiveness of satisfying the interest of the mortgage creditor. The mortgage grants the mortgage creditor a privilege of being able to satisfy his claims from the property with priority over the personal creditors of the property owner. In the event of enforcement from the immovable property, the sum obtained from the auction will first be used to pay the claim of the mortgage creditor and only after that to the other personal creditors of the property owner, as far as the remaining funds are available (Article 1025, $\S \S$ 1, 2, 4, 5 and Article $1026 \S 1$ of the Code of Civil Procedure).

However, the priority of satisfying the mortgage creditor's claim is not absolute, as it gives way to so-called privileged claims by operation of law itself, be it the

${ }^{25}$ Judgement of the Court of Appeal in Szczecin of 4 December 2012, I ACa 504/12. 
Code of Civil Procedure or other special provisions. ${ }^{26}$ The mortgage exists as long as the collateral for which it was established exists. ${ }^{27}$

In any event, however, such priority status cannot be granted under Article 532 of the Civil Code, since any rules laid down in the enforcement provisions would then lose their meaning. It is rightly pointed out that the preference of one group of debts in relation to another is determined by the tenets of legal policy, in particular welfare considerations or reasons of public interest. ${ }^{28}$

Since the mortgage is an erga omnes right, the mortgage creditor has the right to expect that the secured claim is satisfied from the moment it becomes due, taking into account the enforcement privileges. Such a creditor cannot be exposed to the uncertainty that a possible disposal of the mortgaged property will be challenged, with the simultaneous loss of the security and the creditor's expectation that the claim will be satisfied. Such an assumption would undermine the meaning of the mortgage security and would make its effectiveness dependent on events beyond the control of the creditor who established it.

The creditor takes the effort (also, as mentioned above, financial) to establish a mortgage security to have the certainty, which a creditor who has not attempted to establish a physical security does not have. The conviction of certainty of satisfaction of the creditor's claim arises from the provisions of law which make ineffective in relation to his right any disposal regarding the encumbered property. The legislature seems to respond to him: "Do not worry about the fate of the encumbered property, because you will always be able to secure your claim by this property".

This certainty is enhanced by the provisions on mortgage protection (Article $91 \mathrm{ff}$. of the Act on land registers and mortgage). Without questioning the need to protect actio Pauliana-backed creditors, this cannot be done at the expense and to the detriment of creditors secured by physical collaterals or other creditors establishing securities, even personal ones. Their protection, in view of the nature of the right from which this protection derives, is of primary importance, without prejudice to the limitations arising from the enforcement rules.

It is argued that where an actio Pauliana-backed creditor competes with creditors of a third party in the course of enforcement against the third party's assets, there is a need, as in the case of any enforcement procedure, to draw up a plan for the distribution of the sum obtained from the enforcement. In such circumstances, when Article 532 of the Civil Code does not specify the category in which the claim

${ }^{26}$ S. Rudnicki, Ustawa o księgach wieczystych i hipotece. Przepisy o postępowaniu w sprawach wieczystoksieggowych. Komentarz, Warszawa 2005, p. 211.

27 Resolution of the Supreme Court of 18 October 2013, III CZP 64/13, OSNC 2014, no. 708, item 70

${ }^{28}$ P. Telenga, [in:] Kodeks postepowania cywilnego, vol. 2: Komentarz do art. 730-1217, ed. A. Jakubecki, Warszawa 2017, p. 493. 
of the actio Pauliana-backed creditor should be satisfied, Article 1025 of the Civil Code applies, which places receivables enjoying the so-called statutory priority in the fifth category, on a par with receivables secured by physical collateral. ${ }^{29}$

It is also necessary to remember about the plan of distribution of funds of the bankruptcy estate made by the trustee in bankruptcy. The legislature is also aware of the existence of a conflict of interest between the creditors secured by physical collateral on the assets of the bankruptcy estate and the privileged creditors in the distribution of the bankruptcy estate funds. Article 346 of the Bankruptcy Law is an attempt to find a limited compromise between these conflicting interests. ${ }^{30}$

The observation of social life suggests that banks largely use physical collaterals. ${ }^{31}$ Considering the mentioned public interest, when creating the order of satisfaction of claims, assuming absolute priority under Article 532 of the Civil Code, we could cause an infringement of the banking system and the bank security, which could even threaten the collapse of the public finance system.

Therefore, while respecting the right of both the creditor affected by the risk of his claims not being satisfied as a result of the debtor's actions and the creditors of the bankrupt debtor, one may in no way eliminate the special protection ensured to the creditor by a physical collateral, including mortgage-backed. The establishment of a mortgage security does not result in some fashion or acting "just in case", but is the result of a fully and widely accepted conviction that it is the "strongest" security of a claim. Thus, even the need to protect the interest of actio Pauliana creditors cannot nullify these principles.

The priority described in Article 532 of the Civil Code is not therefore an absolute priority. Pursuant to Article 65 (1) of the Act on land registers and mortgage, the property may be encumbered with a right (mortgage) by virtue of which the creditor may seek satisfaction of the claim from the real property regardless of changes in ownership of the object of pledge or mortgage (Article 306 (1) of the Civil Code and Article 65 (1) of the Act on land registers and mortgage) and with priority over personal creditors of the owner of the property. The right of a mortgage creditor in the event of the debtor's bankruptcy goes so far that the bankruptcy estate may also be used, pursuant to Article 92 (2) of the Bankruptcy Law, to pay the interest payable by the bankrupt, even after the date of the declaration of bankruptcy, if the claim is secured, among others. by mortgage.

${ }^{29}$ A. Janiak, [in:] Kodeks cywilny. Komentarz, vol. 3: Zobowiązania. Część ogólna, ed. A. Kidyba, Warszawa 2014, p. 896.

${ }^{30}$ A. Jakubecki, [in:] A. Jakubecki, F. Zedler, Prawo upadłościowe i naprawcze, Warszawa 2010, p. 737.

${ }^{31}$ See J. Pisuliński, [in:] System Prawa Prywatnego, vol. 4, p. 531. 
Clearly, that interest can be paid only from the item on which the security is backed. This rule applies to any security valid at the time of the declaration of bankruptcy.

The moment of its establishment is only relevant for reasons of examination of the priority of the right and the order in which claims are to be satisfied. In such circumstances, there may also be a concern about the effectiveness of the protection of a creditor who does not benefit from any physical collateral, in the event of debtor's transactions which encumber his assets physically. Such concerns are unjustified if we consider the content of the aforementioned Article 59 of the Civil Code and the possibilities offered by this provision where the debtor takes an action the performance of which renders wholly or partly impossible the satisfaction of the claim of a third party.

The definition of the relationship between the protection provided to the creditor in the provisions on actio Pauliana or the provisions of Bankruptcy Law and the protection of creditors secured by physical collateral affects the content of classic civil law institutions, such as pledge or mortgage, and affects the assessment of the practical effectiveness of these securities. For these reasons, it is impossible to forget about the conditions that result from the regulations and concepts of Property Law and the Law of Obligations when looking for appropriate relations. ${ }^{32}$ Therefore, the effectiveness of mortgage as a right in rem cannot be replaced by the priority referred to in Article 532 of the Civil Code.

Therefore, it is beyond discussion that the priority of satisfaction of a claim may not be given to the debtor's creditor over third party creditors who have obtained a right of pledge or mortgage on the object of a transaction intentionally detrimental to the creditor. The opposite assumption would undermine the effectiveness of these rights as rights in rem. ${ }^{33}$

The provision of Article 532 of the Civil Code, while creating the principle of priority, does not interfere with and does not change the general principles of law. As regards the effects of declaration of bankruptcy, Article 43 of the Bankruptcy Law states that "after the declaration of bankruptcy, securities in the form of establishment of a temporary court administrator or compulsory administration shall discontinue as soon as the assets of the debtor in bankruptcy covered by administration by the trustee in bankruptcy. Other securities applied by the court after the filing of the bankruptcy petition shall discontinue on the day of declaration of bankruptcy".

The Act does not mention that any security, also of a physical nature, should expire as a result of declaration of bankruptcy. Therefore, the legislature does not

32 A. Jakubecki, Jeszcze w kwestii statusu wierzyciela rzeczowego w postępowaniu upadłościowym, "Przegląd Sądowy" 1999, no. 10, p. 136.

33 J. Pisuliński, Ochrona wierzyciela w razie niewypłacalności dlużnika - propozycja nowego ujęcia, [in:] Prawo kontraktów, eds. Z. Kuniewicz, D. Sokołowska, Warszawa 2017, p. 370. 
make the durability and effectiveness of the security dependent on the debtor's financial situation. It would also be difficult to accept the dependence of effectiveness and durability of a physical collateral on the creditor's attempt to satisfy it by the actio Pauliana system. The disposal of the encumbered item by the debtor does not, as a rule, entail any detriment to the creditor. ${ }^{34}$

It must be assumed that, if the legislature were willing to consider that the effect of bankruptcy was the expiry of the security, also physical one, the legislature would have clearly expressed that effect. A similar assessment is justified with regard to the effectiveness of the creditor's security in the event of the debtor's insolvency. ${ }^{35}$

There is no provision of such content in the Bankruptcy Law, and Article 70 (1) provides that "the provisions on the exclusion from the bankruptcy estate shall not apply to property, claims and other property rights transferred by the bankrupt to the creditor in order to secure the claim. The statutory provisions on pledge and claims secured by a pledge shall apply mutatis mutandis to those items and to claims thus secured".

It follows from that provision, first, that the chattel bailed is part of the bankruptcy estate and, secondly, that the physical security does not expire and the creditors benefiting from the security will be able to satisfy their claim in accordance with the rules laid down in the provisions on pledge and according to the order in which the claim is to be satisfied.

Of course, there may be doubts whether, since the legislature is taking up the issue of pledge, the rules on real property on which the mortgages are established are different. It would be difficult to accept differentiation of the effects of physical securities.

The legislature only addresses the issues of items subject to a pledge, because pledge is a transaction with a tangible object and consequently the bailed item comes out of the debtor's hands. The legislature does not address the issue of other types of pledge, because items thus encumbered do not generally come out of the debtor's hands.

A similar situation exists for mortgaged properties. Thus, the absence of a positive provision, unlike that on pledge, does not justify the thesis that in the case of a mortgage, the mortgage expires as a result of the bankruptcy. It would be against the law to differentiate physical securities, since each of them is a right effective erga omnes.

The situation of a mortgage-backed claim in the event of bankruptcy is determined by Article 345 of the Bankruptcy Law, and the mortgage-backed claim is

34 The Supreme Court held in the judgement of 13 April 2012 (III CSK 214/11, LEX no. 130777) that rendering a legal transaction ineffective through actio Pauliana was inadmissible if the creditor was not affected.

35 Judgement of the Court of Appeal in Szczecin of 4 December 2012, I ACa 504/12. 
to be satisfied from the sum obtained from the liquidation of the encumbered item according to their priority, less the costs related to the sale and certain unsecured claims referred to in Article 346 (1) of the Bankruptcy Law.

It is, therefore, necessary to share A. Jakubecki's view that "Article 532 of the Civil Code does not exclude the provisions on the primacy of rights disclosed in the land register as well as the privileges referred to in Article 346 of the Bankruptcy Law". ${ }^{36}$

It should also be borne in mind that Article 81 (1) of the Bankruptcy Law states that after the declaration of bankruptcy the components of the bankruptcy estate cannot be encumbered, including by mortgage. The question about the priority of the mortgage creditor may necessarily concern only those mortgage creditors whose security was established before the date of the declaration of bankruptcy. It would be difficult to question in these circumstances the primacy rooted in a right in rem before the priority described in Article 532 of the Civil Code.

\section{CONCLUSIONS}

To sum up, creditors using physical security (including mortgage) have the right to seek satisfaction of their claims with priority over creditors described in Article 532 of the Civil Code.

The system of creditor protection provided in Polish law by the construct of actio Pauliana raises a number of other doubts, e.g. regarding the possibility of using the aforementioned system to protect public receivables. ${ }^{37}$ It, therefore, appears that in order to eliminate the doubts concerning the use of the provisions on actio Pauliana for creditor protection, it is necessary to clarify these provisions. In the area that is the main subject of interest in this article, it is reasonable to make a proposal for the law as it should stand (de lege ferenda) by suggesting that the wording of Article 532 of the Civil Code be supplemented by its $\S 2$, stating that "The priority referred to in the provision does not prejudice the priority obtained by creditors on the basis of special provisions". Such a change would confirm, reasonably as it seems, that the priority granted by the legislature to the creditors on the basis of the provisions on actio Pauliana is not of an absolute nature.

${ }^{36}$ A. Jakubecki, Glosa do uchwaty SN z 10.02.2006 r., III CZP 2/06, "Orzecznictwo Sądów Polskich" 2008, no. 6, item 71. Similarly, i.a., W. Popiołek, op. cit., p. 253.

37 The request of the Ombudsman for Civil Rights to the Constitutional Tribunal of 1 December 2016 to find that Article $527 \S 1$ of the Civil Code, in so far as it applies by analogy to the claiming public debts in the form of actio Pauliana is incompatible with Articles 2 and 84 of the Polish Constitution. 


\section{REFERENCES}

\section{Literature}

Bodio J., Wymagania formalne apelacji i skutki ich nieuwzględnienia, [in:] Jus et remedium. Księga jubileuszowa Profesora Mieczystawa Sawczuka, eds. A. Jakubecki, J.A. Strzępka, Warszawa 2010.

Gudowski J., Poglad na apelacje, [in:] Aurea praxis. Aurea theoria. Ksiega pamiatkowa ku czci Profesora Tadeusza Erecińskiego, eds. J. Gudowski, K. Weitz, vol. 1, Warszawa 2011.

Jakubecki A., [in:] A. Jakubecki, F. Zedler, Prawo upadłościowe i naprawcze, Warszawa 2010.

Jakubecki A., Glosa do uchwały SN z 10.02.2006 r., III CZP 2/06, "Orzecznictwo Sądów Polskich" 2008, no. 6, item 71 .

Jakubecki A., Jeszcze w kwestii statusu wierzyciela rzeczowego w postępowaniu upadłościowym, "Przegląd Sądowy" 1999, no. 10.

Jakubecki A., Ogłoszenie upadtości strony procesu cywilnego - uwagi na tle nowelizacji Kodeksu postepowania cywilnego, "Przegląd Sądowy" 2007, no. 7-8.

Janiak A., [in:] Kodeks cywilny. Komentarz, vol. 1: Część ogólna, ed. A. Kidyba, Warszawa 2012.

Janiak A., [in:] Kodeks cywilny. Komentarz, vol. 3: Zobowiazania. Część ogólna, ed. A. Kidyba, Warszawa 2014.

Klaczak P., Mularski K., Skarga pauliańska a zaspokojenie przez dlużnika jednego z jego wierzycieli, "Transformacje Prawa Prywatnego" 2020, no. 4.

Kubas A., Rozszerzona skuteczność wierzytelności, "Studia Cywilistyczne" 1969, vol. 13-14.

Longchamps de Bérier R., Zobowiąania, Poznań 1999.

Machnikowski P., [in:] Kodeks cywilny. Komentarz, ed. E. Gniewek, Warszawa 2006.

Ohanowicz A., Przepis art. 59 k.c. a tzw. ius ad rem, "Państwo i Prawo" 1966, no. 11.

Pastuszka A., Prawo procesu cywilnego, Lublin 1937.

Pisuliński J., [in:] System Prawa Prywatnego, vol. 4: Prawo rzeczowe, ed. E. Gniewek, Warszawa 2005.

Pisuliński J., Ochrona wierzyciela $w$ razie niewypłacalności dlużnika - propozycja nowego ujęcia, [in:] Prawo kontraktów, eds. Z. Kuniewicz, D. Sokołowska, Warszawa 2017.

Popiołek W., [in:] Kodeks cywilny, vol. 2: Komentarz do artykułów 450-1088, ed. K. Pietrzykowski, Warszawa 2011.

Pyziak-Szafnicka M., [in:] System Prawa Prywatnego, vol. 6: Prawo zobowiązań - część ogólna, ed. A. Olejniczak, Warszawa 2009.

Pyziak-Szafnicka M., Glosa do wyroku SN z 24.10.2002, II CK 396/02, "Orzecznictwo Sądów Polskich" 2003, no. 11, item 141 .

Pyziak-Szafnicka M., Ochrona wierzyciela w razie niewypłacalności dlużnika, Warszawa 1995.

Rudnicki S., [in:] Komentarz do kodeksu cywilnego. Księga pierwsza. Część ogólna, eds. S. Dmowski, S. Rudnicki, Warszawa 2004.

Rudnicki S., Ustawa o ksieggach wieczystych i hipotece. Przepisy o postępowaniu w sprawach wieczystoksiegowych. Komentarz, Warszawa 2005.

Sychowicz M., [in:] Komentarz do kodeksu cywilnego. Księga trzecia. Zobowiązania, ed. G. Bieniek, vol. 1, Warszawa 2007.

Telenga P., [in:] Kodeks postepowania cywilnego, vol. 2: Komentarz do art. 730-1217, ed. A. Jakubecki, Warszawa 2017.

Wójcik M.P., [in:] Kodeks postępowania cywilnego. Komentarz, ed. A. Jakubecki, Warszawa 2012. 


\title{
Case law
}

Decision of the Supreme Court of 13 August 1997, I CKN 207/97.

Decision of the Supreme Court of 5 September 1997, III CKN 152/97.

Decision of the Supreme Court of 26 October 2005, V CK 776/04.

Judgement of the Supreme Court of 28 November 1995, I CRN 218/95.

Judgement of the Supreme Court of 13 April 2012, III CSK 214/11, LEX no. 130777.

Judgement of the Court of Appeal in Szczecin of 4 December 2012, I ACa 504/12.

Resolution of the Supreme Court of 18 October 2013, III CZP 64/13, OSNC 2014, no. 708, item 70.

\begin{abstract}
ABSTRAKT
Przedmiotem niniejszego artykułu jest kwestia intensywności ochrony interesów osoby, która weszła w stosunki zobowiązaniowe. Opisano instytucje wykorzystywane do zabezpieczenia wierzytelności, przy czym wątpliwości pojawiają się, gdy zabezpieczenia potęgują się w razie ogłoszenia upadłości dłużnika. Nie każde z przedsięwzięć gospodarczych kończy się sukcesem. Niejednokrotnie przedsiębiorca, z niezależnych powodów, nie jest w stanie zaspokoić swoich wierzycieli. Wierzyciele z kolei, mając świadomość ryzyka powiązanego z wejściem w zobowiązanie, zazwyczaj starają się o zabezpieczenia. W związku z tym warto zastanowić się, jak należy traktować zabezpieczenia w przypadku niewypłacalności dłużnika. W opracowaniu wskazano, że „samozabezpieczenia" wierzyciela - osobowe i rzeczowe - mają pierwszeństwo przed wierzycielami uzyskującymi pierwszeństwo wskutek ubezskutecznienia czynności dłużnika na podstawie przepisów o skardze pauliańskiej. Autor broni stanowiska, zgodnie z którym pierwszeństwo, o którym mowa w art. 532 k.c., nie jest pierwszeństwem bezwzględnym czy absolutnym. Problemy poruszone w opracowaniu są przedmiotem zainteresowania wielu przedstawicieli doktryny i sądów. Co więcej, w odniesieniu do ich treści Rzecznik Praw Obywatelskich sformułował pytania o ich zgodność z Konstytucją RP. Przyjęcie przez Polskę modelu gospodarki rynkowej sprawiło, że problematyka ta dotyczy nie tylko Polski. Dla obrony zapatrywania o pierwszeństwie zabezpieczenia podjętego przez wierzycieli przed pierwszeństwem, którego źródłem jest skarga pauliańska, zaprezentowano szereg argumentów, a dla wyeliminowania wątpliwości co do wzajemnego stosunku pierwszeństw do zaspokojenia wierzytelności sformułowano stosowny wniosek de lege ferenda.
\end{abstract}

Słowa kluczowe: polskie prawo prywatne; ochrona wierzyciela; niewypłacalność dłużnika; skarga pauliańska; zabezpieczenie wierzytelności; pierwszeństwo bezwzględne; upadłość 